\title{
The Successful Mode of Tennis Development Strategy Reflects the Development of Sports in China.
}

\author{
Peng Wang \\ Dongfang College, ShanDong University of Finance and Economics, Taian, Shandong, 271000
}

Keywords: Tennis, Development strategy, Success mode, The comprehensive quality

\begin{abstract}
This paper makes a preliminary study on the development of sports in China through the successful mode of tennis development strategy, and analyzes the successful mode of tennis development strategy combined with the existing materials, as well as the development context and influence of sports development in China. This paper briefly discusses the reasons for this phenomenon, and finally puts forward some reasonable Suggestions for the development of sports in China.
\end{abstract}

\section{Introduction}

Tennis is an important part of the world sports forest. The humanistic spirit and core ideas expressed by tennis culture also play an indispensable role in the history of human development. As a product of the development of western society, tennis was introduced into China through the opium war in the form of cultural colonization.

How to learn and learn from the core of tennis has become a topic worth discussing at present. The work of Chinese tennis still faces many difficulties, and the popularization of Chinese tennis is also a long way off. In this paper, through study the history of tennis sports and culture, and summarizes the problems in the Chinese tennis popularization, deep thinking about tennis development countermeasures in our country, at the same time of promote cultural exchange between Chinese and western, promote the localization process of Chinese tennis.

\section{The Discussion on the Successful Model of Tennis Development Strategy is of Great Significance To the Study of College Students' Sports Reform in China}

This is the need of The Times and the goal of the development of colleges and universities. Health and the health not only is a new stage in the development of human civilization, follow or human beings, nature and society harmonious development of the objective law and the sum total of material and spiritual achievement, education in colleges and universities is the last link of the school education system, as a major platform for the construction of spiritual civilization should be more proactive in health and health education, from the Angle of the human and the nature harmonious, to carry out teaching activities, to protect and build good ecological environment at the same time, also promote China's economic construction, political construction, cultural construction, social construction whole process of progress, the further realization of the social civilization progress, Take the road of sustainable development. University education as the last leg of school physical education and the future role in the life education, making the university sports education a lifetime benefit to the college students, especially the tennis development strategy successful model research foundation for the sustainable development of the society. In under the background of university sports reform, we should be existing resources, continue to deepen the tennis development strategy successful pattern research, thus better cultivate college students' sports core accomplishment, will get the effective implementation of the cultivation of sports skills and apply, for the society cultivate a batch of more comprehensive talents with personality and vitality. Therefore, the successful model of tennis development strategy is of great significance to the study of Chinese sports development. 


\section{The successful model of tennis development strategy influences the development of Chinese sports}

As the Internet and the popularity of intelligent technology improve, related education workers in colleges and universities should actively make college sports skills fit the requirements of the relevant training patterns and ecological civilization, and promote the teaching reform work. College students sports skills training college education related staff time to all-round development, the sustainable development of the society for the purpose of college tennis sports skills training activities, for tennis development strategy under the successful pattern of the development of sports of our country present situation analysis, the following aspects such as:

(1)The successful model of tennis development strategy promotes the reform of college sports in China. As now the number of undergraduate and graduate students receiving higher education gradually increase, accelerate the speed of China's economic and social development greatly, and the project of cultivating college students put forward higher requirements. Although the country's most colleges and universities have the corresponding college education management system, but in terms of tennis development strategy successful model, there are still many gaps, college education management system in colleges and universities still exist many problems to be solved. Under the new situation, the current situation of education management of college sports still does not meet the requirements of ideal state, and there are still many problems that need to be solved, which deserve further exploration. If we want to promote the innovation of education management mechanism in colleges and universities through the study on the successful model of tennis development strategy, we must always take students as the main body and carry out education activities. Such as tennis course of credit system and the main minor system, dual degree or related system reform and innovation, and constantly improve the modern university sports teaching management methods, adhere to promote the reform of college sports teaching management system, make full use of existing education resources of tennis teaching management appraisal system, perfect and further achieve the goal of college physical education in colleges and universities management, develop a more comprehensive high-quality talent.

(2)To play tennis and sports skills. Activities for tennis sports skills competition and knowledge lectures, but students widespread attention is not high, to some extent, this method can guide the student to participate in college tennis sports course, under the influence of the rules of competition activities of rewards and punishments, realize the importance of tennis education in colleges and universities, and in the future study, work and life time of inheritance and innovation is an important cultural mission of natural science knowledge, promote the progress of the construction of the tennis course in colleges and universities. However, this approach also has many disadvantages that cannot be ignored. It can only see results in a short period of time, but does not have the concept of sustainable development. Although the current university has carried out some knowledge about tennis sports development of sports skills lectures, guide the students with high thinking consciousness involved in the reform of college sports construction, to better promote the progress of the college sports development in our country. However, university education lacks corresponding measures in the allocation of tennis course construction resources, which results the college students cannot pay attention to the concept of people-oriented in the process of cultivating tennis sports skills. Therefore, the construction of physical education curriculum in just stays at the theoretical level, will not be able to realize the long-term development and progress, this needs us continuously improve tennis training methods, build a power for the reform of college sports.

\section{Research on the way to promote the successful training of tennis development strategy in China}

Reform of college sports construction is not a person or a team will be able to complete, nor can the complete of utility in a relatively short period of time, especially the pattern based on the development strategy of promoting the development of our country sports tennis training ways of 
research need the long time adhere to the construction of colleges and universities sports education workers, pay attention to the ways of the construction of the college tennis sports. Especially in colleges and universities should take ecological civilization construction, continuously improve, innovation, whole hog for ecological civilization construction of the heart, the following for the pattern based on the development strategy of promoting the development of our country sports tennis training approach to study and put forward several constructive Suggestions:

(1)Increase investment in the successful model of tennis development strategy research of sports skills resources. Most colleges and universities in our country sports development research of the physical education workers need to work hard, also need to students actively between tennis development strategy mode, success will be university sports construction goals into specific tennis education practice, which is reflected on the specific behavior of colleges and universities sports reform and the construction of the guiding role of college tennis education, colleges and universities of higher education sports development guidance to college students tennis development strategy successful model research path has the vital practical significance, which requires colleges and universities increased strategy successful mode research into the development of tennis sports skills, resources, Especially on some tennis sports facilities space into, dare to be unique, dare to innovation, so that the group of all staff, students and other related groups feel successful tennis development strategy pattern formation in the process of the importance of healthy development, and then have a qualification and capacity building has its own characteristics, attaches great importance to the born of the construction of the sports colleges and universities, so as to further promote the effective and efficient way for college sports education reform in China.

(2)Strengthen management of tennis education and continue education training for education workers. In order to achieve efficient management of tennis education, it is required that enough tennis education staff join the construction team and participate in the management of college sports education. But now most of the basic skills of tennis education workers is not so ideal, do not meet the needs of the development of our country university sports innovation, leading to physical education in colleges and universities related university management work progress is slow, and heavy task, tennis teachers and the heart is unable to do. And part of tennis sports in colleges and universities work team for the construction of the attention degree is not high, employment of graduate student of grade two and grade three students as part-time teacher, participate in college sports in the student management work, their management ability compared with other senior tennis teachers, strong creative, innovative management style, but also can appear some problems, led to the student by the university tennis education management degree is not high. In addition, some tennis teacher part-time job, do not have enough time and energy to participate in the tennis theory knowledge of related advanced ability to continue education and training, in the process of the university tennis education management work can not meet the requirement of the university sports education goal of work. Therefore, increasing the management staff of tennis education and continuing education training for the staff of tennis education can promote the research on the successful model of tennis development strategy in China to a certain extent.

\section{Conclusion}

It is better to anticipate than to anticipate, colleges and universities must clear pattern successful tennis development strategy goal and overall direction, intensify efforts to promote physical education under the new situation of university management system reform innovation. College sports education management goal to implement as soon as possible, we must dare to lead the trend of the university education management, from the pattern construction as the starting point, people-oriented, make full use of existing resources, faculty and students in the process of strategy research tennis success pattern formation of basic needs and to deal with problems and work to promote the college physical education management work. 


\section{References}

[1] HuanWang. The investigation and analysis of the sports facilities and the status quo of social opening in changchun university [J]. Fighting (martial arts science), 2013,(9):114-117

[2] ZhiZhang. Reflections on the problems in the development of women's tennis professionalism of China [J]. Sports research and education, 2015,30(3):65-68.

[3]Yanfei Chen. The enlightenment of sports education model to school PE curriculum reform [J]. Journal of Physical Education 2005(3):92-94.

[4] WenMeng, HaiyanLI, Feasibility study on the implementation of sports education model in college physical education curriculum -- a case study of tennis teaching reform in nanjing institute of engineering [J]. Journal of Sports Adult Education, 2011,27(05):84-85

About the author:

Peng Wang. male, born on December 02, 1978. Native place: Xintai city, Shandong province. Education background: master degree, title: lecturer. Research direction: education training of sports. 